\title{
Preparation of polymeric aluminum ferric sulphate from waste residue of aluminum industry
}

\author{
Li jun $^{1}$, Ju Yanmei ${ }^{1, a}$ \\ ${ }^{1}$ Guangxi Vocational\&Technical Institute of Industry, Nanning, China, 530001
}

\begin{abstract}
Polymeric aluminum ferric sulphate(PAFS) was prepared from high-sulfur bauxite flotation tailings and red mud by roasting, acid leaching and polymerization. The effects of leaching temperature, leaching time, liquid-solid ratio on the leaching rate of $\mathrm{Al}^{3+}$ and $\mathrm{Fe}^{3+}$ were investigated. The optimal leaching conditions are as follows: leaching temperature $100^{\circ} \mathrm{C}$, leaching time $90 \mathrm{~min}$, sulfuric acid concentration $4.5 \mathrm{~mol} / \mathrm{L}$ and liquid-solid ratio $5 \mathrm{mg} / \mathrm{L}$. Infrared spectroscopy and X-ray diffraction analysis was carried out on the PAFS prepared under the optimum process parameters. The characterization of PAFS shows that the synthesized PAFS had polymeric aluminum, iron and hydroxyl structures. Wastewater disposal test of synthetic PAFS shows that the removal rates of COD, turbidity and chromaticity are $45.61 \%, 75 \%$ and $94.18 \%$, respectively.
\end{abstract}

\section{Introduction}

High-sulfur bauxite flotation tailings is a kind of solid waste discharged from the bauxite ore beneficiation process $^{[1]}$. Red mud, a highly alkaline residue, is a solid waste in production of alumina ${ }^{[2]}$. With increasingly stringent environmental protection policies, how to dispose of red mud and bauxite tailings at low cost has become one of the problems that restrict the sustainable development of the aluminum industry. A lot of research has been conducted on red mud and bauxite tailings, which are mainly used for the production of construction materials ${ }^{[3-5]}$, filling materials ${ }^{[6,7]}$, refractory materials ${ }^{[8]}$, functional materials ${ }^{[9-11]}$, etc. However, there are still problems such as low value-added products or high process energy consumption or limited solid waste consumption, resulting that most of produced red mud and bauxite flotation tailings are stored in landfills ${ }^{[12]}$. Based on the principle of complementary composition among multiple solid wastes, a study was conducted on the preparation of polymeric aluminium ferric sulfate flocculant (PAFS) from red mud and bauxite tailings, aiming to promote the reduction and resourceization of solid wastes in aluminum industry and to achieve the purpose of turning waste into treasure.

\section{Experimental}

\subsection{Materials}

High-sulfur bauxite flotation tailings and red mud were collected from an alumina plant of Chinalco, composed of particles less than 100 screen mesh. The chemical composition of raw material is shown in table 1.
Mineralogical composition of raw material was established by X-ray diffraction. As shown in Fig.1, goethite, hematite, quartz, and boehmite were identified as main phases of red mud; diaspora, pyrite, illite, kaolinite, and anatase were identified as main phases of high-sulfur bauxite flotation tailings.

Table 1. Chemical composition of raw material

\begin{tabular}{|c|c|c|c|c|c|}
\hline Composition & $\mathrm{Fe}_{2} \mathrm{O}_{3}$ & $\mathrm{TiO}_{2}$ & $\mathrm{Na}_{2} \mathrm{O}$ & $\mathrm{K}_{2} \mathrm{O}$ & $\mathbf{C a O}$ \\
\hline Red mud & 67.01 & 3.92 & 1.725 & 0.078 & 0.35 \\
\hline Tailings & 26.3 & 2.25 & 0.13 & 1.19 & 0.53 \\
\hline Composition & $\mathbf{S i O}_{2}$ & $\mathbf{A l}_{2} \mathbf{O}_{3}$ & $\mathbf{M g O}$ & $\mathbf{S}$ & LOI \\
\hline Red mud & 5.01 & 7.90 & 0.09 & 0.095 & 13.24 \\
\hline Tailings & 8.99 & 36.81 & 0.27 & 19.10 & -- \\
\hline
\end{tabular}

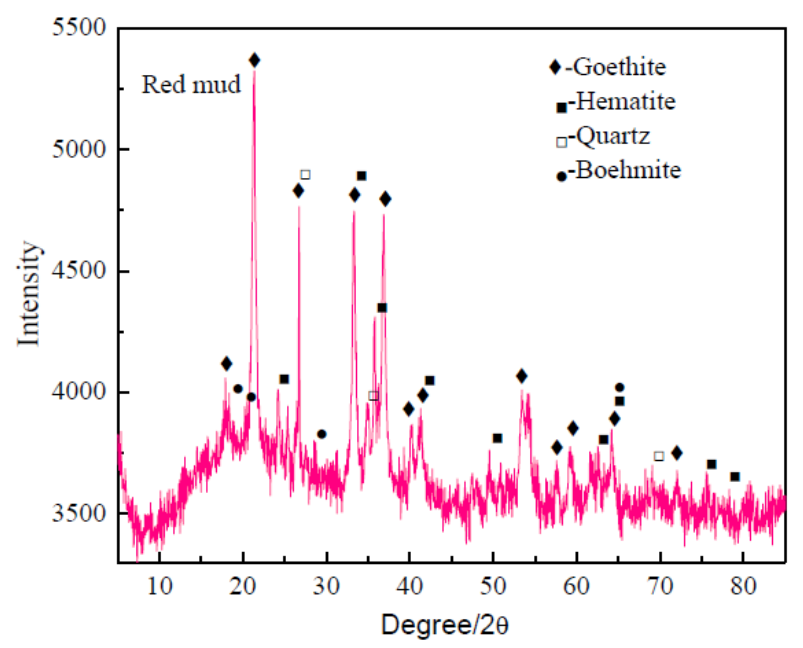

a Corresponding author: juyanmei@foxmail.com 


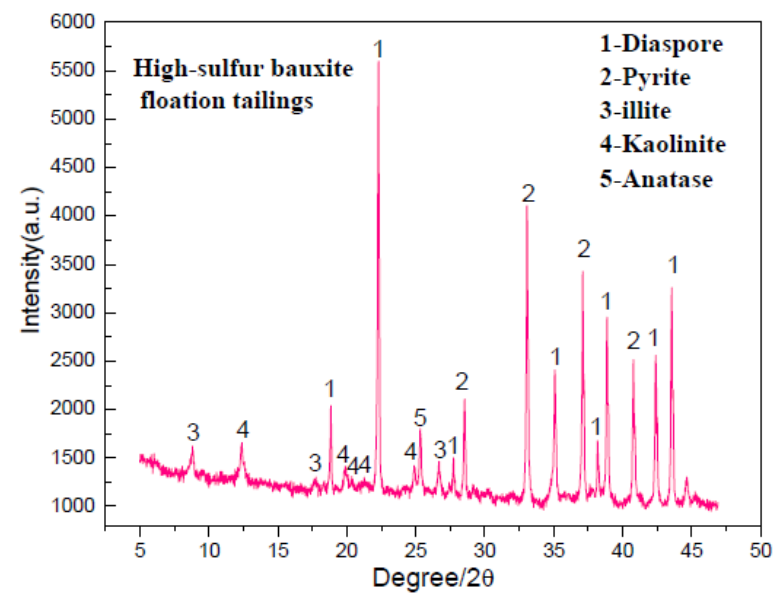

Figure 1. XRD pattern of raw material

\subsection{Apparatus}

Chemical reagents : Concentrated sulfuric acid 98\%; Analytical pure sodium bicarbonate; 35\% hydrogen peroxide.

Equipment: Electronic Balance (AUW120D); Rex laboratory $\mathrm{pH}$ meter(PHS-3E); Electrothermal thermostatic water bath(DK-S22/S24). The water bath apparatus is shown in Fig.2, which is used to leach aluminum and iron from the waste slags.

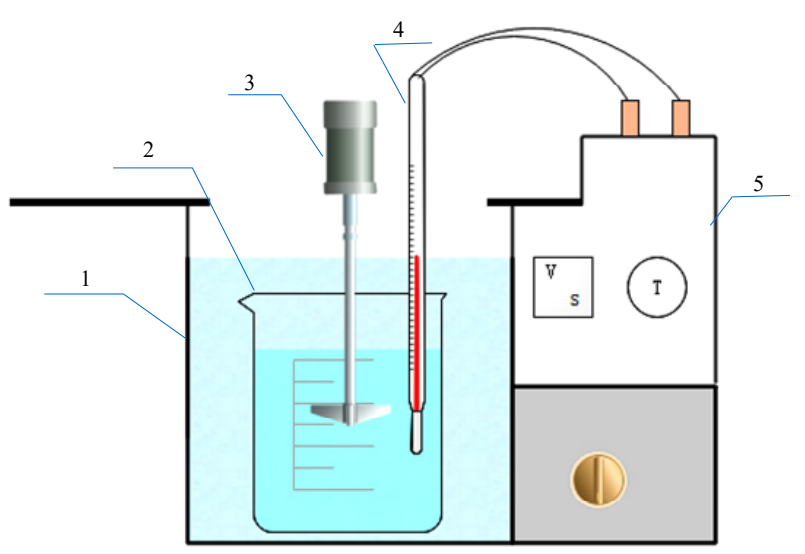

1- Thermostatic water bath; 2- Beaker; 3- Stirrer; 4- Contact thermometer; 5- Control box

Figure 2 Schematic diagram of aluminum and iron leaching experimental device

\subsection{Experimental method}

With red mud and tailings as the main raw materials, the polymerized aluminum sulfate iron flocculant is synthesized by acid leaching, oxidation, alkalization, maturation and aging processes. The reaction mechanism of different process steps are shown in table 2 .

Table 2. Flocculant preparation mechanism

\begin{tabular}{|c|c|}
\hline Process steps & Mechanism of reaction \\
\hline $\begin{array}{c}\text { Microwave } \\
\text { roasting of } \\
\text { tailings }\end{array}$ & $\mathrm{Fe}_{2} \mathrm{~S}=2 \mathrm{FeS}_{1+x}+(1-x) / 2 \mathrm{~S}_{2}$ \\
\hline Acid leaching & $\mathrm{S}_{2}+2 \mathrm{O}_{2}=2 \mathrm{SO}_{2}$ \\
\hline
\end{tabular}

\begin{tabular}{|c|c|}
\hline $\begin{array}{c}\text { (red mud and } \\
\text { sintered slag of } \\
\text { tailings ) }\end{array}$ & $\mathrm{Fe}_{2} \mathrm{O}_{3}+\mathrm{H}_{2} \mathrm{SO}_{4}=\mathrm{Al}_{2}\left(\mathrm{SO}_{4}\right)_{3}+3 \mathrm{H}_{2} \mathrm{O}$ \\
\hline $\begin{array}{c}\text { Alkalinization } \\
\text { (Aluminum } \\
\text { and iron } \\
\text { leaching } \\
\text { solution) }\end{array}$ & $\mathrm{Al}_{2}\left(\mathrm{SO}_{4}\right)_{3}+\mathrm{nH}_{2} \mathrm{O}=\mathrm{Al}_{2}(\mathrm{OH})_{\mathrm{n}}\left(\mathrm{SO}_{4}\right)_{3-\mathrm{n} / 2}+\mathrm{n} / 2 \mathrm{H}_{2} \mathrm{SO}_{4}$ \\
$\mathrm{Fe}_{2}\left(\mathrm{SO}_{4}\right)_{3}+\mathrm{nH}_{2} \mathrm{O}=\mathrm{Fe}_{2}(\mathrm{OH})_{\mathrm{n}}\left(\mathrm{SO}_{4}\right)_{3-\mathrm{n} / 2}+\mathrm{n} / 2 \mathrm{H}_{2} \mathrm{SO}_{4}$ \\
Polymerization & $\mathrm{mAl}_{2}(\mathrm{OH})_{\mathrm{n}}\left(\mathrm{SO}_{4}\right)_{3-\mathrm{n} / 2}=\left[\mathrm{Al}_{2}(\mathrm{OH})_{\mathrm{n}}\left(\mathrm{SO}_{4}\right)_{3-\mathrm{n} / 2}\right]_{\mathrm{m}}$ \\
$\mathrm{kFe}_{2}(\mathrm{OH})_{\mathrm{n}}\left(\mathrm{SO}_{4}\right)_{3-\mathrm{n} / 2}=\left[\mathrm{Fe}_{2}(\mathrm{OH})_{\mathrm{n}}\left(\mathrm{SO}_{4}\right)_{3-\mathrm{n} / 2}\right]_{\mathrm{k}}$
\end{tabular}

The preparation process is shown in Fig.3.

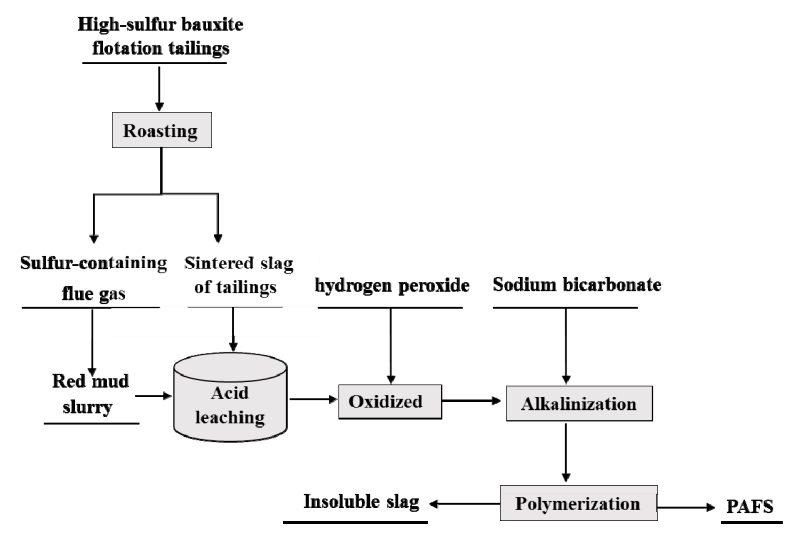

Figure 3 Polymerized aluminum sulfate iron preparation process flow chart

The sulfur in the high sulfur bauxite flotation tailings was removed by roasting at $600^{\circ} \mathrm{C}$ for $20 \mathrm{~min}$. The sulfur-containing flue gas from the roasting process are absorbed by red mud slurry; then the slag and red mud slurry are leached by a certain concentration of sulfuric acid to obtain a high concentration of aluminum and iron leachate; the leachate is finally made into polymerized aluminum sulfate and iron flocculant through alkalization, polymerization and maturation.

\section{Results and discussion}

\subsection{Optimization of acid leaching process}

The flue gas generated during the roasting of high sulfur bauxite flotation tailings is absorbed by the red mud slurry. A small amount of aluminum and iron ions are leached from the red mud slurry. In order to obtain a high and properly proportioned concentration of aluminum and iron ions, sintered slag is added to the slurry, which is half the weight of the red mud, and then further leached with sulfuric acid.

\subsubsection{Effect of temperature on leaching rate of $\mathrm{Al}^{3+}$ and $\mathrm{Fe}^{3+}$}

The relationship between leaching rate of aluminum and iron and temperature is shown in Fig.4, which was obtained under the conditions of sulfuric acid concentration of $5.30 \mathrm{~mol} / \mathrm{L}$, liquid-to-solid ratio of 6 $\mathrm{mL} / \mathrm{g}$, and reaction time of $90 \mathrm{~min}$.

It is clear from the illustrations that both $\mathrm{Al}^{3+}$ and $\mathrm{Fe}^{3+}$ leaching ratio increased with the increase of heating 
temperature. The reasonable explanation is that the Brownian motion between molecules intensifies and more effective collisions are completed as the temperature increases. Although the increase in temperature is beneficial to improve the leaching rate, the increase in temperature will make the energy consumption increase. Considering comprehensively, $100^{\circ} \mathrm{C}$ was selected as the suitable acid leaching temperature.

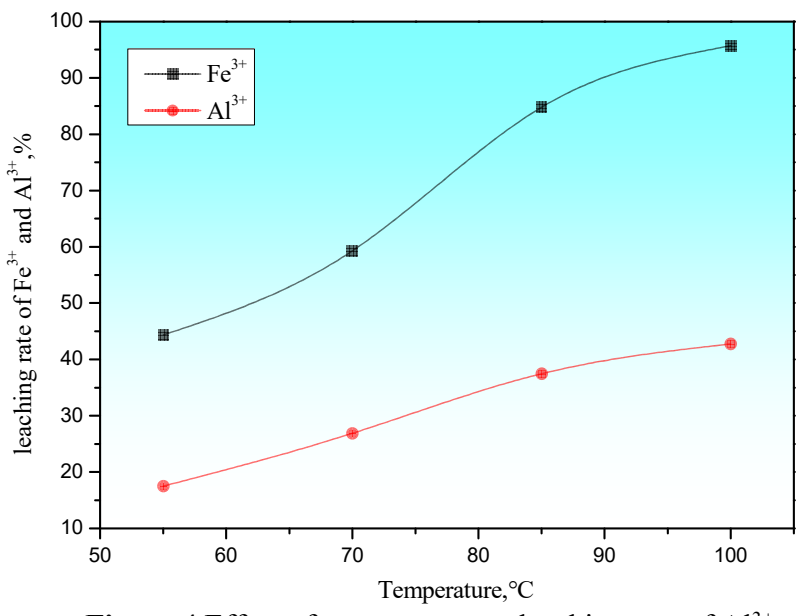

Figure 4 Effect of temperature on leaching rate of $\mathrm{Al}^{3+}$ and $\mathrm{Fe}^{3+}$

\subsubsection{Effect of time on leaching rate of $\mathrm{Al}^{3+}$ and $\mathrm{Fe}^{3+}$}

The relationship between leaching rate of aluminum and iron and time is shown in Fig.5, which was obtained under the conditions of sulfuric acid concentration of $5.30 \mathrm{~mol} / \mathrm{L}$, liquid-to-solid ratio of $6 \mathrm{~mL} / \mathrm{g}$, and reaction temperature of $100^{\circ} \mathrm{C}$.

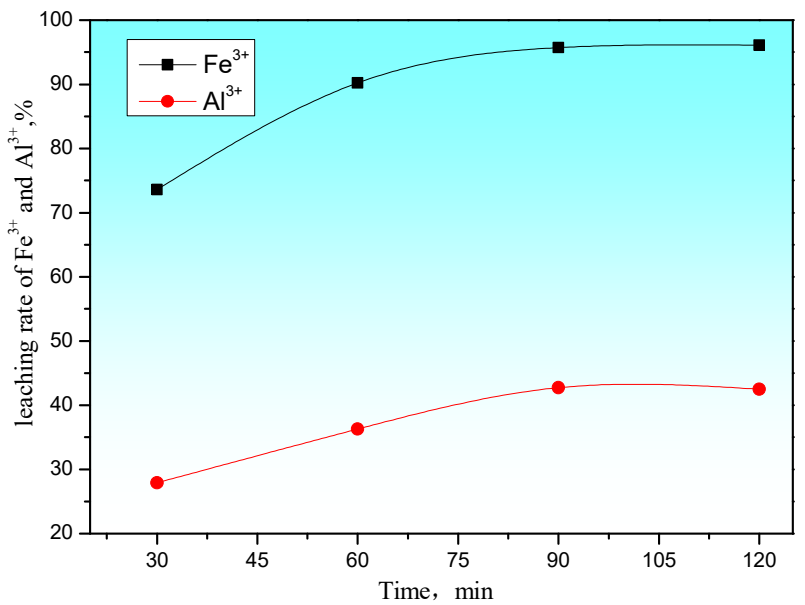

Figure 5 Effect of time on leaching rate of $\mathrm{Al}^{3+}$ and $\mathrm{Fe}^{3+}$

As seen in Fig.5, the leaching rate of aluminum and iron increased with the increase of leaching time. For the first $90 \mathrm{~min}$, the aluminum and iron leaching rates increased significantly, and then the increase was not obvious. Considering that the leaching process was carried out at high temperature, the suitable acid leaching time was determined to be $90 \mathrm{~min}$ from the viewpoint of energy consumption and efficiency.

\subsubsection{Effect of sulfuric acid concentration on leaching rate of $\mathrm{Al}^{3+}$ and $\mathrm{Fe}^{3+}$}

The relationship between leaching rate of aluminum and iron and sulfuric acid concentration is shown in Fig.6, which was obtained under the conditions of reaction temperature of $100^{\circ} \mathrm{C}$, liquid-to-solid ratio of $6 \mathrm{~mL} / \mathrm{g}$, and reaction time of $90 \mathrm{~min}$.

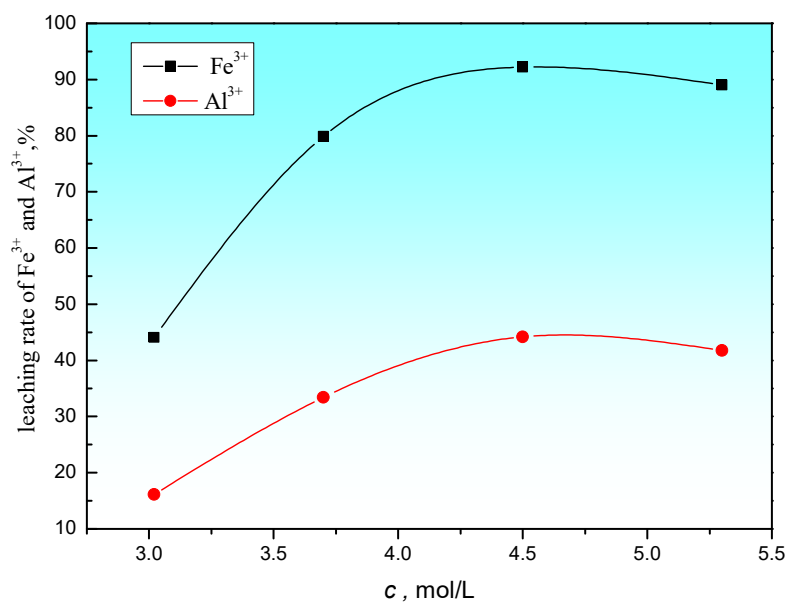

Figure 6 Effect of sulfuric acid concentration on leaching rate of $\mathrm{Al}^{3+}$ and $\mathrm{Fe}^{3+}$

As shown in Figure 6, the leaching rates of $\mathrm{Al}^{3+}$ and $\mathrm{Fe}^{3+}$ first increased and then decreased with the increase of sulfuric acid concentration. Specifically, when the sulfuric acid concentration is less than $4.5 \mathrm{~mol} / \mathrm{L}$, the higher the acid concentration, the more molecules can be activated per unit volume, which is more conducive to the leaching reaction. However, when the sulfuric acid concentration is higher than $4.5 \mathrm{~mol} / \mathrm{L}$, sulfuric acid reacts with aluminum and iron oxides to produce sulfate, which is enriched on the oxide surface and deteriorates the leaching conditions. Therefore, the high concentration of sulfuric acid does not promote the leaching of metal oxides. It is more appropriate to choose $4.5 \mathrm{~mol} / \mathrm{L}$ sulfuric acid for leaching.

\subsubsection{Effect of liquid-to-solid ratio on leaching rate of $\mathrm{Al}^{3+}$ and $\mathrm{Fe}^{3+}$}

The relationship between leaching rate of $\mathrm{Al}^{3+}$ and $\mathrm{Fe}^{3+}$ and liquid-to-solid ratio is shown in Fig.8, which was obtained under the conditions of reaction temperature of $100^{\circ} \mathrm{C}$, sulfuric acid concentration of $4.5 \mathrm{~mol} / \mathrm{L}$, and reaction time of $90 \mathrm{~min}$.

It can be seen from Fig.7 that the leaching rate of $\mathrm{Al}^{3+}$ and $\mathrm{Fe}^{3+}$ increases with the increase of liquid-solid ratio. Especially when the liquid-solid ratio is less than 5 $\mathrm{mg} / \mathrm{L}$, it has a significant effect on the leaching rate. Considering comprehensively, the liquid-solid ratio of 5 $\mathrm{mg} / \mathrm{L}$ is more reasonable. 


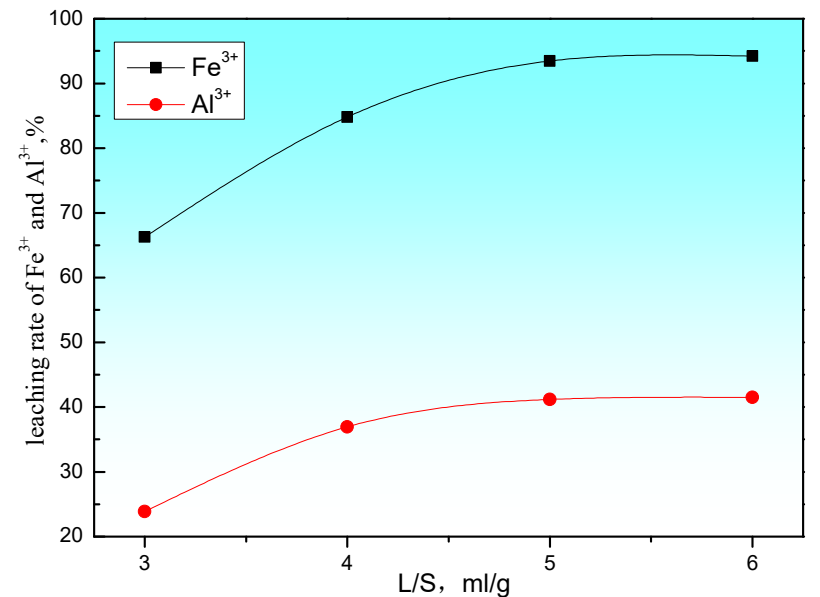

Figure 7 Effect of liquid-solid ratio on leaching rate of $\mathrm{Al}^{3+}$ and $\mathrm{Fe}^{3+}$

\subsection{Leachate polymerization and product characterization}

$\mathrm{Al}^{3+}$ and $\mathrm{Fe}^{3+}$ are polymerized by adding alkalizer to the leaches, which are obtained under optimal leaching conditions. The polymerization process involves the following chemical reactions ${ }^{[13]}$.

$$
\begin{aligned}
& A l^{3+} \mathrm{Al}(\mathrm{OH})^{2+} \stackrel{\mathrm{OH}}{\longleftrightarrow} \mathrm{Al}_{2}(\mathrm{OH})_{2}^{4+} \stackrel{\mathrm{OH}}{\longleftrightarrow} \mathrm{Al}_{x}(\mathrm{OH})_{y}^{(3 \mathrm{r}-\mathrm{y})+} \stackrel{\mathrm{OH}}{\longleftrightarrow} \mathrm{Al}_{x} \mathrm{O}(\mathrm{OH})_{y}^{(3 \mathrm{x}-2 \cdot 2 \mathrm{z})+} \\
& \mathrm{Fe}^{3+} \stackrel{\mathrm{OH}}{\longleftrightarrow} \mathrm{Fe}(\mathrm{OH})^{2+} \stackrel{\mathrm{OH}^{-}}{\longleftrightarrow} \mathrm{Fe}_{2}(\mathrm{OH})_{2}^{+4} \stackrel{\mathrm{OH}}{\longleftrightarrow} \mathrm{Fe}_{4}(\mathrm{OH})_{6}^{6+} \stackrel{\mathrm{OH}}{\longleftrightarrow}\left[\mathrm{Fe}_{2}(\mathrm{OH})_{4}\right]_{\frac{n}{2}}^{n+}
\end{aligned}
$$

According to the literature ${ }^{[14,15]}, 1 \mathrm{~mol} / \mathrm{L}$ sodium bicarbonate solution was used as the alkalizer, and the polymerization temperature was controlled at $85^{\circ} \mathrm{C}$. The alkalizer was slowly added and stirred until the $\mathrm{pH}$ of the solution reached 2.95. After the alkalization, the solution was matured for $4 \mathrm{~h}$ at $60^{\circ} \mathrm{C}$ with a stirring rate of 300 $\mathrm{r} / \mathrm{min}$. Finally, the liquid PAFS was obtained by static cool down for 24h.

PAFS (liquid) was dried under vacuum and low temperature environment. XRD and IR patterns of the prepared PAFS samples are shown in Fig.8.

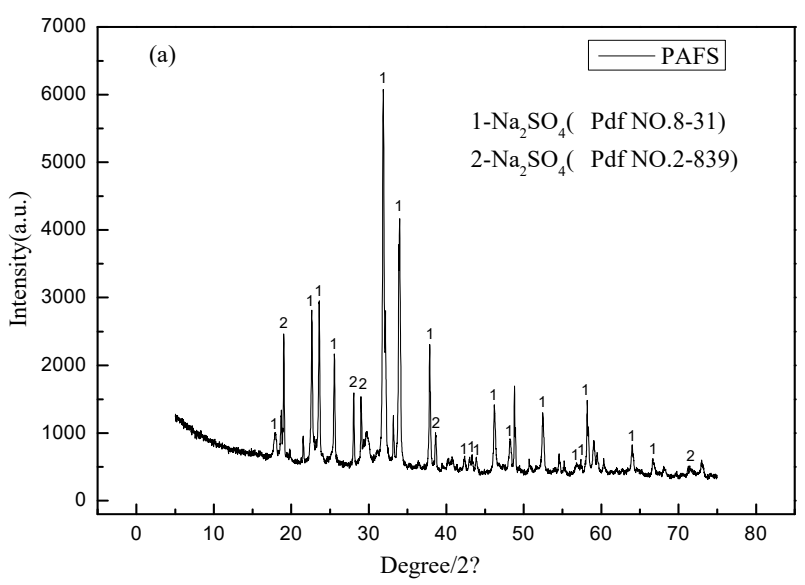

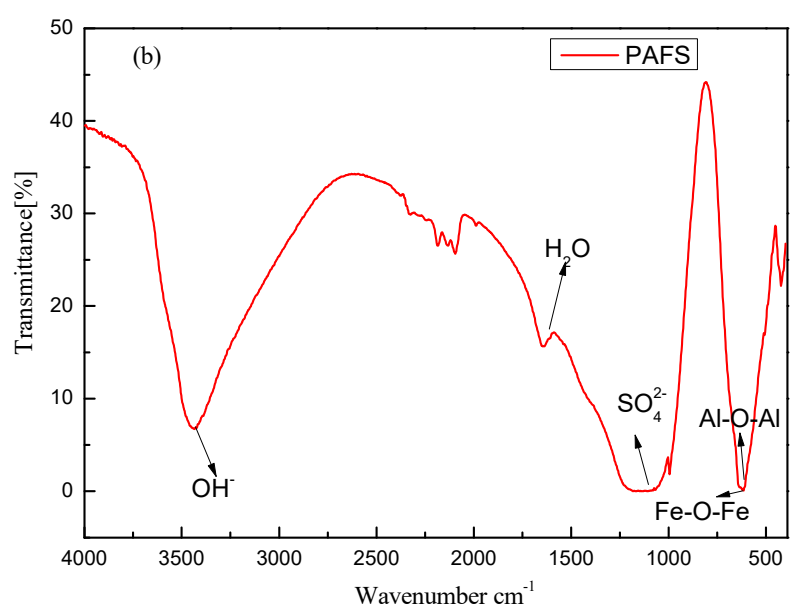

Figure 8 XRD and Infrared spectroscopy of the prepared PAFS

It can be seen from Fig.8 (a) that only the diffraction peak of sodium sulfate exists, but there are no diffraction peaks such as aluminum sulfate, ferric sulfate and sodium bicarbonate. It can be inferred that $\mathrm{Al}^{3+}$ 、 $\mathrm{Fe}^{3+}$ and $\mathrm{SO}_{4}{ }^{2-}$ in the solution polymerize into amorphous material.

As seen in Fig.8(b), the absorption peak formed between 3400 and $3550 \mathrm{~cm}^{-1}$ is generated by the stretching vibration of the OH-group, and the area occupied by this peak is wide, so it is presumed that the hydroxyl content in PAFS is high. The absorption peak near $1635 \mathrm{~cm}-1$ is due to the bending vibration of adsorbed water, coordination water and crystalline water; the $\mathrm{SO}_{4}^{2-}$ absorption peak at $1000 \sim 1200 \mathrm{~cm}^{-1}$ is generated by the stretching vibration of $\mathrm{SO}_{4}{ }^{2-}$. In the low wave number interval from 553 to $732 \mathrm{~cm}^{-1}$, there are also AlOH-Al $\left(732 \mathrm{~cm}^{-1}\right)$ and $\mathrm{Fe}-\mathrm{OH}-\mathrm{Fe}\left(671 \mathrm{~cm}^{-1}\right)$ in-plane bending vibration peaks ${ }^{[16]}$, but the intensity of both is greatly diminished. Rather, the bending vibration peaks interact to form a peak between 610 and 640, which is consistent with the results of the literature ${ }^{[17]}$.

\subsection{Industrial wastewater disposal test}

The industrial wastewater was obtained from a chemical plant in Xinxiang, Henan Province, with original $\mathrm{pH}=6.52, \mathrm{COD}=198.6 \mathrm{mg} / \mathrm{L}$, turbidity $=260 \mathrm{NUT}$, and chromaticity $=8$ (times). Experimental synthetic PAFS and commercial PAFS (purchased from Zhengzhou Yisheng Chemical Co., Ltd.) were used for flocculation tests, respectively. The initial $\mathrm{pH}$ of the wastewater was adjusted to 7.0 and then the mass of the PAFS injection was controlled to be $0.18 \%$ of the wastewater. The treatment effect is shown in Table 3, which shows that the COD removal performance of the experimental synthetic PAFS is slightly lower than that of commercial product, while the turbidity and chromaticity removal rates are comparable.

Table 3. Flocculation test results of industrial wastewater

\begin{tabular}{|c|c|c|c|}
\hline Flocculant & COD/\% & Chromaticity/\% & Turbidity/\% \\
\hline Synthetic PAFS & 45.61 & 75.0 & 94.18 \\
\hline $\begin{array}{c}\text { Commercial } \\
\text { PAFS }\end{array}$ & 50.65 & 75.0 & 93.23 \\
\hline
\end{tabular}




\section{Conclusions}

In this paper, solid wastes (red mud and bauxite tailings) from the aluminum industry were used as raw materials to synthesize PAFS by roasting, acid leaching and polymerization, and the following conclusions can be obtained.

(1) It is feasible to synthesize PAFS by roasting, acid leaching and polymerization with red mud and bauxite tailings as raw materials. This technology is expected to promote the reduction of solid waste in aluminum industry and turn waste into treasure.

(2) The optimal leaching conditions of $\mathrm{Al}^{3+}$ and $\mathrm{Fe}^{3+}$ are as follows: leaching temperature $100^{\circ} \mathrm{C}$, leaching time $90 \mathrm{~min}$, sulfuric acid concentration $4.5 \mathrm{~mol} / \mathrm{L}$ and liquid-solid ratio $5 \mathrm{mg} / \mathrm{L}$.

(3) Wastewater disposal test shows that the COD removal performance of the experimental synthetic PAFS is slightly lower than that of commercial product, while the turbidity and chromaticity removal rates are comparable.

\section{References}

1. Dongyang Ma, Zhendong Wang, Min Guo, Mei Zhang, Jingbo Liu. Feasible conversion of solid waste bauxite tailings into highly crystalline 4A zeolite with valuable application[J]. Waste Management,2014,34(11).

2. Khairul M A, Zanganeh J , Moghtaderi B . The composition, recycling and utilisation of Bayer red mud [J]. Resources, Conservation and Recycling, 2018, 141:483-498.

3. YANG H Z, CHEN C P, PAN L J, et al. Preparation of double-layer glass-ceramic/ceramic tile from bauxite tailings and red mud[J].Journal of the European Ceramic Society, 2009, 29(10): 1887-1894.

4. YANG H Z, CHEN C P, SUN H W, et al. Influence of heat-treatment schedule on crystallization and microstructure of bauxite tailing glass - ceramics coated on

5. YAN Zuxing.The application and research of cement-red mud concrete. Concrete, 2000 (10):1820(in Chinese).

6. Mangen $\mathrm{Mu}$, Xiaozhen Gao, Taoming Guo,Xinping Hu. Experimental Study of Goaf Filling Materials Based on Red Mud[J]. IOP Conference Series: Materials Science and Engineering,2018,301(1).

7. Yong Guang Fang,Zheng Ke Chen,Yu Qian. Red Mud Powders Applied on Filling Rubber Composite Material[J]. Advanced Materials Research, 2013, 2735.

8. LI Y, REN Y, PEI D, et al.Mechanism of pore formation in novel porous permeable ceramics prepared from steel slag and bauxite tailings[J].ISIJ International, 2019: ISIJINT-2018-782.
9. SHEN X J, QIU G B, YUE C S, et al.Multiple copper adsorption and regeneration by zeolite $4 \mathrm{~A}$ synthesized from bauxite tailings[J].Environmental Science and Pollution Research, 2017, 24(27): 21829-21835.

10. A. Cruceanu,R. Zăvoianu,O. D. Pavel,M. Florea,L. Mara. Alternative valorization of red mud waste as functional materials with catalytic activity for sulfide oxidation in wastewater[J]. International Journal of Environmental Science and Technology, 2018,15(4).

11. Yanju Liu,Ravi Naidu,Hui Ming. Red mud as an amendment for pollutants in solid and liquid phases[J]. Geoderma,2011,163(1).

12. Novais Rui M,Carvalheiras João,Seabra Maria P,Pullar Robert C,Labrincha João A. Innovative application for bauxite residue: Red mud-based inorganic polymer spheres as $\mathrm{pH}$ regulators.[J]. Journal of hazardous materials,2018,358.

13. Tian Baozhen, Zhang Yun. The preparation and application of Al-Fe co-polymer inorganic coagulant[J]. Industrial water treatment, 1998, 18(1): 17-19. (in Chinese)

14. Zhu G, Zheng H, Chen $\mathrm{W}$, et al. Preparation of a composite coagulant: Polymeric aluminum ferric sulfate (PAFS) for wastewater treatment[J]. Desalination, 2012, 285: 315-323.

15. Wang W H, Liu Q W, Ning Z W . Preparation of polymeric aluminum ferric sulphate from industryial dross. Industrial Water Treatment, 2000.

16. PARKER D R, BERTSCH P M.Identification and quantification of the"Al3" tridecameric aluminum polycation using ferron[J].Environmental Science \& Technology, 1992, 26(5): 908-914.

17. Zhao R, Liu ZA, Chang Y, et al. Preparation of PAFS Cationic Flocculant in Various Fe3+/Al3+ Molar Ratio [J]. Journal of Inner Mongolia Normal University(Natural Science Edition), 2011, 40(5): 508-511 (in Chinese). 